\title{
Relative Assessment of Channel Fading Models in Wireless Networks
}

\author{
P. Nandhini, G. Kavitha, N. Priya, Nikita Sharma
}

\begin{abstract}
With a specific extreme target to update and test the structure's possibility to negate clouding, we basically need to appear and reenact the correspondence condition under some darkening channel for plotting of a correspondence framework. The trademark of clouding channel is extraordinary and complex for various causing conditions. As necessities be, sensible darkening model for a specific correspondence situation is basic in such way. Rayleigh darkening and Ricean clouding models are the most routinely utilized little scale models in remote correspondence till date. In any case, after the nearness of helpful radio correspondence, the game plan of a situation has been changed to finish convenientce of transmitter or beneficiary. Hence we have to change the darkening model as well. This paper considers diverse darkening models-Rayleigh clouding, Rice a darkening and smart Rayleigh darkening utilizing. The re-authorizing happens as expected show that Fast Rayleigh Fading model is most legitimate for adaptable radio conditions which continue on through thick clouding.
\end{abstract}

\section{INTRODUCTION}

In a boss among the most clearly comprehended occasions of remote correspondence, for example adaptable correspondence frameworks, the transmitting gathering contraption or Base Station are orchestrated over an apex and radiate at most ludicrous permitted control. In any case, the getting advantageous station may either be adaptable and is open underneath some encompassing building. Thus, the channel is affected by the encompassing structures-cars, structures, and so forth. This makes some debasement in the got hail quality. The direct of any radio channel between a transmitter and a beneficiary can be a because of any of the running with marvels: Way occurrence: These difficulties are an aftereffect of free-space disaster, digestion of the transmission medium (for example the air) and diffusing of signs themselves when they are weakened. Thusly hardship is customarily spoiling with square or forward effect of the division among transmitter and beneficiary

pennant over a brief timeframe period or voyaged confined. It is brought about by between no under two changes of the

Revised Manuscript Received on July 22, 2019.

P. Nandhini, Department of CSE, Bharath Institute of Higher Education and Research, Chennai, Tamilnadu, India.

Ms. G. Kavitha Department of CSE, Bharath Institute of Higher Education and Research, Chennai, Tamilnadu, India.

Ms. N. Priya Department of CSE, Bharath Institute of Higher Education and Research, Chennai, Tamilnadu, India.

Nikita sharma, Student,Department of CSE, Bharath Institute of Higher Education and Research, Chennai, Tamilnadu, India transmitted banner which get together at the recipient at somewhat extraordinary conditions. These waves, called . Shadowing: For this condition, the picked up hail control changes in perspective of extensive things impeding the spread course among transmitter and specialist. The shadowing influence is typically delineated by log-standard dispersing. [1],[3],[5]

Darkening: Fluctuations in the plentifulness of a radio multipath waves, converge at the specialist radio wire to give a resultant flag which can move all around in abundance and stage. Ponder of clouding is subdivided as takes after:

Enormous scale clouding: It works out as intended because of improvement over massive locales. It helps in getting ready course hardship as a part of division. This is reliably delineated like a mean-way mishap and a log usually coursed collection about the mean.

Little scale darkening: It is an aftereffect of little changes in position. Little scale clouding proposes changes in flag plentifulness and stage which might be an immediate consequence of little changes in the spatial arranging between a beneficiary and a transmitter. Underneath figure gives a graphical portrayal of the effectively indicated darkening considers. Fig.1. about here.

\section{A. Ricean Fading Model}

In little scale darkening, when the standard associates at the gatherer by several different ways and one of them, normally a perceivable pathway (LOS) hail is extensively more grounded than the others, by then such channel is named as Ricean Fading Channel and the abundancy of got flag is said to be Rice Distributed. [7],[ 9] ,[11]

\section{DARKENING MODELS}

Following piece merges three summed up darkening models that are on an extremely essential dimension used to portray little scale clouding. [13], [15] ,[ 17]

\section{A. Rayleigh Fading Model}

Rayleigh darkening happens when there is no noticeable pathway between the transmitter and expert. The darkening rate is affected by how energetic the expert and furthermore transmitter or the wrapping things are moving. Pdf of Rayleigh Fading Distribution. [14],[ 16], [18]

\section{B. Quick Rayleigh Fading Model}

This model is utilized for structures where either the transmitter or beneficiary is adaptable with fast, by then the regular planning stops wasting time and how quickly the channel

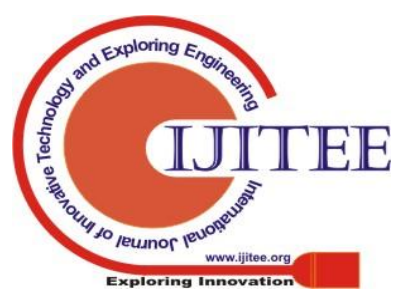


clouds, will be influenced by how energetic they are moving. [20],[22], [24]

By virtue of relative development between the transmitter and the beneficiary, each multipath wave encounters clear move in the rehash. This move in the got hail rehash is called as Doppler's work day. In such a condition, little scale darkening itself is asked for as Time-Variance of channel and Time-Spreading of.The terms immediate and smart clouding propose the rate at which size and stage change compelled by the channel on the standard changes. [25],[27],[29]

Coordinate darkening creates when the understandability time of the redirect is enormous as to the put off need of the channel. Lively winning trim happens when the adequacy and stage change compelled by the channel moves and isn't determined. It happens when the lucidity time of the channel is small concerning put off confinement of the channel

In each down to earth sense, it has been seen that, such a trademark is seen explicitly, phenomenally thick and altogether dispersive locale. In most powerful systems like Wireless Sensor Networks, the clouding influence is out and out progressively veritable and such a darkening is then demonstrated utilizing Hyper-Rayleigh Fading Model. [31],[33],[35]

\section{DIVERSION ENVIRONMENT}

This piece gives the reasons for energy of the excitement condition used to reproduce the outcomes and depiction of parameters set. Here, a situation is made that incorporates 7 focuses, out of which node1 is the PAN facilitator (Full Function Device) while the other three, node2 to 7 are transmitters (Reduced Function Devices). Eventually, we have related unquestionable darkening models in this condition. A see of the equivalent is given be-low. Fig.5. about here.

\section{RESULTS}

In perspective of the above amusement, following outcomes are refined with few application layer parameters, in sort of visual blueprints.

\section{A. Typical Jitter}

Jitter is utilized as an extent of the abnormality after some period of the package dormancy over a framework. Thusly, jitter in any correspondence situation ought to be least. Before long since the condition taken here is amazingly darkened (WSN or some other fundamentally thick structure) it will drive forward through high jitter. Thusly, among all the three open darkening models-Rayleigh, Ricean, Fast Rayleigh, Fast Rayleigh gives most ludicrous jitter be-cause Fast Rayleigh can model such structures in the most ideal way. So it unequivocally measures the impact of darkening than Rayleigh or Ricean models.

\section{B. Mean Packets Received}

This chart demonstrates that amidst transmission, out of all transmit-ted bundles just an entire of 14 packs could reach in
Rayleigh and Ricean appear. Regardless, if there should rise an occasion of Fast Rayleigh represent, 57 bundles came to. This displays Fast Rayleigh show has favored execution over different models.

\section{Common start to finish Delay}

D. Common start to finish delay hints the time taken for a bundle to be transmitted over a structure from source to objective. For any system, it ought to be as low as could reasonably be typical. Quick Rayleigh Model shows less start to finish yield a spark than the other two models. Thusly we can express that Fast Rayleigh show modify remarkable darkening conditions better that the other two models. [37],[39],[41]

\section{E. Throughput}

Throughput is the run of the mill rate of profitable message de-uniform over a correspondence channel. In like manner, in any net-work, throughput ought to be high. In the copied condition, mean enter throughput was $2500 \mathrm{bits} / \mathrm{sec}$. Regardless, in light of the impact of darkening, the groups proceeded with accident and the general throughput is diminished. Here since the demonstrated situation is astoundingly arranged to clouding, it is best appeared Fast Rayleigh Model than Rayleigh or Ricean models giving maxi-mum throughput estimation of $3200 \mathrm{bits} / \mathrm{sec}$ nearly. [38],[40],[42]

\section{CONCLUSION}

On the begin on above outcomes, following closures can be drawn.

I. Since the situation includes 7 focus focuses set in close region. This locations for the most part a thick situation.

II.Application layer parameters-jitter, demonstrate bundles got, start to finish yield and throughput displays perfect respects for quick Rayleigh appear so to speak.

III. This surmises, out of all the three darkening models, smart Rayleigh clouding model shows favored outcomes over the other two. Along these lines, we can express that rapid Rayleigh darkening is most proper for such thick systems.

\section{REFERENCES}

[1] Kumaravel A., Rangarajan K.,Algorithm for automaton specification for exploring dynamic labyrinths,Indian Journal of Science and Technology,V-6,I-SUPPL5,PP-4554-4559,Y-2013

[2] P. Kavitha, S. Prabakaran "A Novel Hybrid Segmentation Method with Particle Swarm Optimization and Fuzzy C-Mean Based On Partitioning the Image for Detecting Lung Cancer" International Journal of Engineering and Advanced Technology (IJEAT) ISSN: 2249-8958, Volume-8 Issue-5, June 2019

[3] Kumaravel A., Meetei O.N.,An application of non-uniform cellular automata for efficient cryptography,2013 IEEE Conference on Information and Communication Technologies, ICT 2013,V-,I-,PP-1200-1205,Y-2013

[4] Kumarave A., Rangarajan K.,Routing alogrithm over semi-regular tessellations,2013 IEEE Conference on Information and Communication Technologies, ICT 2013,V-,I-,PP-1180-1184,Y-2013

[5] P. Kavitha, S. Prabakaran "Designing a Feature Vector for Statistical Texture Analysis of Brain Tumor" International Journal of Engineering and Advanced Technology (IJEAT) ISSN: 2249-8958, Volume-8 Issue-5, June 2019

[6] Dutta P., Kumaravel A.,A novel approach to trust based 
identification of leaders in social networks,Indian Journal of Science and Technology,V-9,I-10,PP--,Y-2016

[7] Kumaravel A., Dutta P.,Application of Pca for context selection for collaborative filtering,Middle - East Journal of Scientific Research,V-20,I-1,PP-88-93,Y-2014

[8] Kumaravel A., Rangarajan K.,Constructing an automaton for exploring dynamic labyrinths,2012 International Conference on Radar, Communication and Computing, ICRCC 2012,V-,I-,PP-161-165,Y-2012

[9] P. Kavitha, S. Prabakaran "Adaptive Bilateral Filter for Multi-Resolution in Brain Tumor Recognition" International Journal of Innovative Technology and Exploring Engineering (IJITEE) ISSN: 2278-3075, Volume-8 Issue-8 June, 2019

[10] Kumaravel A.,Comparison of two multi-classification approaches for detecting network attacks, World Applied Sciences Journal,V-27,I-11,PP-1461-1465,Y-2013

[11] Tariq J., Kumaravel A.,Construction of cellular automata over hexagonal and triangular tessellations for path planning of multi-robots,2016 IEEE International Conference on Computational Intelligence and Computing Research, ICCIC 2016,V-,I-,PP--,Y-2017

[12] Sudha M., Kumaravel A.,Analysis and measurement of wave guides using poisson method,Indonesian Journal of Electrical Engineering and Computer Science,V-8,I-2,PP-546-548,Y-2017

[13] Ayyappan G., Nalini C., Kumaravel A.,Various approaches of knowledge transfer in academic social network,International Journal of Engineering and Technology,V-,I-,PP-2791-2794,Y-2017

[14] Kaliyamurthie, K.P., Sivaraman, K., Ramesh, S. Imposing patient data privacy in wireless medical sensor networks through homomorphic cryptosystems 2016, Journal of Chemical and Pharmaceutical Sciences 92

[15] Kaliyamurthie, K.P., Balasubramanian, P.C. An approach to multi secure to historical malformed documents using integer ripple transfiguration 2016 Journal of Chemical and Pharmaceutical Sciences 92

[16] A.Sangeetha,C.Nalini,"Semantic Ranking based on keywords extractions in the web", International Journal of Engineering \& Technology, 7 (2.6) (2018) 290-292

[17] S.V.GayathiriDevi,C.Nalini,N.Kumar,"An efficient software verification using multi-layered software verification tool "International Journal of Engineering \& Technology, 7(2.21)2018 454-457

[18] C.Nalini,ShwtambariKharabe,"A Comparative Study On Different Techniques Used For Finger - Vein Authentication", International Journal Of Pure And Applied Mathematics, Volume 116 No. 8 2017, 327-333, Issn: 1314-3395

[19] M.S. Vivekanandan and Dr. C. Rajabhushanam, "Enabling Privacy Protection and Content Assurance in Geo-Social Networks", International Journal of Innovative Research in Management, Engineering and Technology, Vol 3, Issue 4, pp. 49-55, April 2018

[20] Dr. C. Rajabhushanam, V. Karthik, and G. Vivek, "Elasticity in Cloud Computing", International Journal of Innovative Research in Management, Engineering and Technology, Vol 3, Issue 4, pp. 104-111, April 2018.

[21] K. Rangaswamy and Dr. C. Rajabhushanamc, "CCN-Based Congestion Control Mechanism In Dynamic Networks", International Journal of Innovative Research in Management, Engineering and Technology, Vol 3, Issue 4, pp. 117-119, April 2018.

[22] Kavitha, R., Nedunchelian, R., "Domain-specific Search engine optimization using healthcare ontology and a neural network backpropagation approach", 2017, Research Journal of Biotechnology, Special Issue 2:157-166

[23] Kavitha, G., Kavitha, R., "An analysis to improve throughput of high-power hubs in mobile ad hoc network" , 2016, Journal of Chemical and Pharmaceutical Sciences, Vol-9, Issue-2: 361-363

[24] Kavitha, G., Kavitha, R., "Dipping interference to supplement throughput in MANET", 2016, Journal of Chemical and Pharmaceutical Sciences, Vol-9, Issue-2: 357-360

[25] Michael, G., Chandrasekar, A.,'Leader election based malicious detection and response system in MANET using mechanism design approach", Journal of Chemical and Pharmaceutical Sciences(JCPS) Volume 9 Issue 2, April - June 2016

[26] Michael, G., Chandrasekar, A.,"Modeling of detection of camouflaging worm using epidemic dynamic model and power spectral density", Journal of Chemical and Pharmaceutical Sciences(JCPS) Volume 9 Issue 2, April - June 2016.

[27] Pothumani, S., Sriram, M., Sridhar, J., Arul Selvan, G., Secure mobile agents communication on intranet,Journal of Chemical and
Pharmaceutical Sciences, volume 9, Issue 3, Pg No S32-S35, 2016

[28] Pothumani, S., Sriram, M., Sridhar , Various schemes for database encryption-a survey, Journal of Chemical and Pharmaceutical Sciences, volume 9, Issue 3, Pg NoS103-S106, 2016

[29] Pothumani, S., Sriram, M., Sridhar, A novel economic framework for cloud and grid computing, Journal of Chemical and Pharmaceutical Sciences, volume 9, Issue 3, Pg No S29-S31, 2016

[30] Priya, N., Sridhar, J., Sriram, M. "Ecommerce Transaction Security Challenges and Prevention Methods- New Approach” 2016 ,Journal of Chemical and Pharmaceutical Sciences, JCPS Volume 9 Issue 3.page no:S66-S68 .

[31] Priya, N.,Sridhar,J.,Sriram, M."Vehicular cloud computing security issues and solutions" Journal of Chemical and Pharmaceutical Sciences(JCPS) Volume 9 Issue 2, April - June 2016

[32] Priya, N., Sridhar, J., Sriram, M. "Mobile large data storage security in cloud computing environment-a new approach" JCPS Volume 9 Issue 2. April - June 2016

[33] Anuradha.C, Khanna.V, "Improving network performance and security in WSN using decentralized hypothesis testing "Journal of Chemical and Pharmaceutical Sciences(JCPS) Volume 9 Issue 2, April - June 2016.

[34] Anuradha.C, Khanna.V, "A novel gsm based control for e-devices" Journal of Chemical and Pharmaceutical Sciences(JCPS) Volume 9 Issue 2, April - June 2016

[35] Anuradha.C, Khanna.V, "Secured privacy preserving sharing and data integration in mobile web environments "Journal of Chemical and Pharmaceutical Sciences(JCPS) Volume 9 Issue 2, April - June 2016.

[36] Sundarraj, B., Kaliyamurthie, K.P. Social network analysis for decisive the ultimate classification from the ensemble to boost accuracy rates 2016 International Journal of Pharmacy and Technology 8

[37] Sundarraj, B., Kaliyamurthie, K.P. A content-based spam filtering approach victimisation artificial neural networks 2016 International Journal of Pharmacy and Technology 83 .

[38] Sundarraj, B., Kaliyamurthie, K.P. Remote sensing imaging for satellite image segmentation 2016 International Journal of Pharmacy and Technology 83 .

[39] Sivaraman, K., Senthil, M. Intuitive driver proxy control using artificial intelligence 2016 International Journal of Pharmacy and Technology $8 \quad 4$.

[40] Sivaraman, K., Kaliyamurthie, K.P. Cloud computing in mobile technology 2016 Journal of Chemical and Pharmaceutical Sciences 92.

[41] Sivaraman, K., Khanna, V. Implementation of an extension for browser to detect vulnerable elements on web pages and avoid click jacking 2016 Journal of Chemical and Pharmaceutical Sciences 92

\section{AUTHORS PROFILE}

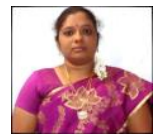

P.Nandhini, Assistant Professor, Department of Computer Science \& Engineering, Bharath Institute of Higher Education and Research, Chennai, India

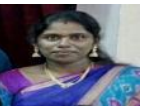

G.Kavitha, Assistant Professor, Department of Computer Science \& Engineering, Bharath Institute of Higher Education and Research, Chennai, India

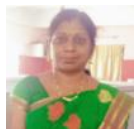

N.priya, Assistant Professor, Department of Computer Science \& Engineering, Bharath Institute of Highe Education and Research, Chennai, India

Nikita sharma, Student, Department of Computer Science \& Engineering, Bharath Institute of Higher Education and Research, Chennai, India 